\title{
Health effects of desert dust storm events in the south-eastern Mediterranean: perceptions and practices of local stakeholders
}

Paraskevi Kinni, ${ }^{1}$ Panayiotis Kouis, ${ }^{1}$ Helen Dimitriou, ${ }^{2}$ Shaked Yarza, ${ }^{3,4}$ Stefania I. Papatheodorou, ${ }^{5,6}$ Eirini Kampriani, ${ }^{7}$ Melanie Charalambous,${ }^{8}$ Nicos Middleton, ${ }^{9}$ Victor Novack, ${ }^{3 \cdot 4}$ Emmanouil Galanakis ${ }^{2}$ and Panayiotis K. Yiallouros ${ }^{1}$

${ }^{1}$ Respiratory Physiology Laboratory, Medical School, University of Cyprus, Nicosia, Cyprus. (Correspondence to: Paraskevi Kinni: kinni.paraskevi@ucy. ac.cy). ${ }^{2}$ Medical School, University of Crete, Heraklion, Crete, Greece. ${ }^{3}$ Clinical Research Center, Soroka University Medical Center, Beer-Sheva, Israel. ${ }^{4}$ Faculty of Health Sciences, Ben-Gurion University of the Negev, Beer-Sheva, Israel. ${ }^{5}$ Department of Epidemiology, Harvard T.H. Chan School of Public Health, Harvard University, Boston, United States of America. ${ }^{6} \mathrm{C}$ yprus International Institute for Environmental \& Public Health; ${ }^{7}$ Department of Social and Political Sciences, University of Cyprus, Nicosia, Cyprus. ${ }^{8}$ Educational Sector, Nursing Services, Ministry of Health, Nicosia, Cyprus. ${ }^{9}$ Department of Nursing, School of Health Sciences, Cyprus University of Technology, Limassol, Cyprus.

\begin{abstract}
Background: The south-eastern Mediterranean experiences frequent desert dust storm events (DDS) that have been shown to be associated with adverse health effects.

Aims: This study assessed the perceptions and practices towards DDS of local authorities and stakeholders from 3 countries in the region, Cyprus, Greece and Israel.

Methods: Between October 2017 and April 2018, we administered a semi-structured questionnaire to regulatory authorities involved in public protection from DDS as well as social stakeholders in the 3 countries. The questionnaire addressed their knowledge regarding DDS, perceptions on the relationship between DDS and health effects and relevant actions taken towards public protection.

Results: Out of 58 stakeholders contacted, 49 participated in the study (84.5\% response rate). Fourteen ( $28.6 \%)$ were regulatory authorities and 35 (71.4\%) were social stakeholders. All responders were familiar with DDS but several underestimated the frequency of events while the majority $(73 \%)$ instinctively reported that elders, children and respiratory patients are susceptible subpopulations. Nevertheless, $71 \%$ were unaware of a national policy on DDS, or considered that this was lacking in their country. Although several stakeholders reportedly receive questions from the public regarding DDS effects, only few reply according to a pre-determined action plan.

Conclusions: Regulatory authorities and social stakeholders in Cyprus, Greece and Israel are characterized by good knowledge of DDS and associated health effects, although implementation of pre-determined action plans for public protection is limited. Future efforts should concentrate on increasing awareness among stakeholders and the public and developing national policies, including effective measures to minimize DDS exposure.

Keywords: desert dust storm, public health, perceptions, questionnaire, stakeholders

Citation: Kinni P; Kouis P; Dimitriou H; Yarza S; Papatheodorou S; Kampriani E; et al. Health effects of desert dust storm events in the south eastern Mediterranean: perceptions and practices of local stakeholders. East Mediterr Health J. 2021;27(11):1092-1101. https://doi.org/10.26719/emhj.21.037

Received: 04/06/20; accepted: 03/01/21

Copyright (C) World Health Organization (WHO) 2021. Open Access. Some rights reserved. This work is available under the CC BY-NC-SA 3.0 IGO license (https://creativecommons.org/licenses/by-nc-sa/3.o/igo).
\end{abstract}

\section{Introduction}

The south-eastern Mediterranean region is affected by frequent and often severe desert dust storms (DDS) lasting several days. These are characterized by extremely high levels of coarse particles with aerodynamic diameter between $2.5 \mu \mathrm{m}$ and $10 \mu \mathrm{m}\left(\mathrm{PM}_{10}\right)$ as well as by increases in fine particles with aerodynamic diameter $<2.5$ $\mu \mathrm{m}\left(\mathrm{PM}_{2.5}\right)(1,2)$. Cyprus, Crete (Greece) and Israel are in the centre of this region experiencing DDS events that originate from both the Sahara and the Arabian Peninsula deserts (3). With reducing precipitation and advancing desertification in the region due to ongoing climatic change, these countries are expected to experience further increases in the frequency and severity of DDS events in the future $(4,5)$.
Consistent evidence from toxicological and epidemiological studies has demonstrated the negative impact of desert dust on cardiorespiratory health. More specifically, data generated from rodent and cellline assays have highlighted the potential of naturally generated particles to inhibit immunoglobulinmediated suppression of inflammation (6), amplify pro-inflammatory cytokines and oxidative stress in respiratory epithelial cells (7) and exacerbate pulmonary eosinophilia (8) and tissue injury (9). Through systemic circulation, smaller particles and toxic substances in desert dust may be transported to all tissues and previous studies have reported increased endothelial dysfunction (10), increased heart rate and mean blood pressure and decreased cardiac contractility (11). These findings are in line with epidemiological studies from around the world, which reported significant associations with both 
respiratory (asthma, pneumonia, chronic obstructive pulmonary disease, allergic rhinitis, coccidiomycosis) and cardiovascular (stroke, arrhythmia, ischaemic heart disease, cerebrovascular disease) outcomes (12). Preliminary evidence, also supports the association of desert dust with reproductive (13), neurological (14) and dermatological (15) health effects, as well as with a higher incidence of meningococcal meningitis (16) and conjunctivitis (17).

In previous years, studies from the region have reported associations of PMio during DDS outbreaks with increased hospital admissions for asthma, chronic obstructive pulmonary disease and cardiovascular disease as well as increased mortality (18-21). However, evidence on the societal concerns and risk perception in relation to DDS events and the associated health problems in these countries is limited (22). Furthermore, there are no data on either the current knowledge and relevant practices of the regulatory authorities or the knowledge and perceptions of involved social stakeholders in the region regarding the health effects of DDS events. As shown before, research in stakeholder perceptions and knowledge has been useful in identifying and prioritizing problems that could and should be resolved, especially in situations where there is no single organization or individual totally in charge, but many are partially involved or affected (23). Thus, in order to introduce effective, easy to implement and sustainable policy interventions towards the mitigation of DDS health effects, it is important to interrelate evidence on the concerns of stakeholders and the capabilities of the regulatory authorities in science-based stakeholder dialogues (24).

The aim of this study was to capture the current state of knowledge and consensus about DDS events and their impact on human health among relevant regulatory authorities (governmental) and societal stakeholders (patients, parents, municipalities, academics, nongovernmental organizations) in Cyprus, Crete (Greece) and Israel.

\section{Methods}

\section{Study participants}

In order to include a wide range of considerations on DDS events, we adopted an inclusive definition of stakeholders (25). As described elsewhere (25-27), we defined stakeholders as "every person or organization who/ which can influence discussions about the development of policy measures for mitigating the health effects of DDS events". The International Risk Governance Council classifies stakeholders in 4 types: regulatory authorities, affected stakeholders, external scientists and civil society organizations (28). However, we adopted some changes to this classification to address the needs of the study. Thus, we considered 2 types of stakeholders: regulatory authorities and social stakeholders. Regulatory authorities were defined as governmental institutions involved in public protection in relation to DDS events. A subcategorization for regulatory authorities was created depending on whether these were educational, health or environmental bodies. Social stakeholders were subdivided into patients' support groups, medical associations, parents' associations, trade unions, municipalities and academic/research institutions.

For the purposes of the study we adopted a judgmental sampling method where participants were identified based on their professional backgrounds, affiliations and experience with DDS events and this allowed us to collect and examine the perceptions and views from different perspectives. In the category of regulatory authorities, representatives holding key positions in organizations that influence the development and management of public health, environmental and education policies were contacted (e.g. ministries of environment, health, labour, education). In the case of municipalities and trade unions, occupational health safety professionals who are involved in the management of occupational health safety risks were identified. Patients' support groups, medical associations and parents' associations were chosen because they act as liaisons with the respective patient groups and the relevant health care and education professionals. In the category of academic/research institutions, we selected experts from various fields who are involved in environmental, air pollution and public health studies.

The survey was conducted between October 2017 and April 2018 and 6 researchers were involved in data collection, 2 from each country.

\section{Data acquisition and survey procedure}

This study employed a cross-sectional survey study design and used semi-structured questionnaires for data collection, which is considered a suitable approach that can yield a significant amount of information related to the phenomenon under study and also be able to focus on the specific study objectives (29).

The semi-structured questionnaires examined the knowledge of participants on DDS events, their perception on the relationship between DDS events and health effects and the relevant actions taken by their organization towards protecting public health from DDS events. The questionnaires were developed through critical comparative analysis and adaptation of existing international questionnaires that were originally used to assess the awareness of professionals in regard to environmental health issues and early warning systems $(30,31)$. The questionnaire was initially developed in English and forward translated in Greek. Two independent bilingual speakers, then back translated the agreed Greek version. The agreed back translation was sent to the authors for their comments and their suggestions were included into the final Greek version. Prior to implementation of the main study, the questionnaires were administered to a restricted sample in order to assess efficacy and applicability and ensure that the questionnaire was culturally acceptable, comprehensible and readable in Cyprus, Crete and Israel. 
Relevant comments were discussed and incorporated to the final version of the questionnaires.

The questionnaire included both open-ended and multiple choice questions. It comprised 2 parts (part A and part B). Part A was common for both types of stakeholders and included 17 questions inquiring about knowledge, perceptions and attitudes towards DDS events. The items in Part B differed according to whether the responder was representing a regulatory authority or a social stakeholder. For the regulatory authorities, the items in Part B examined applied practices and policies for early warning systems for DDS events, while in the case of social stakeholders, Part B included questions on their attitudes towards governmental responses to DDS events as well as their own practices for the mitigation of the health effects of DDS events. (Both parts of the questionnaire, translated into English, are available from the authors on request.)

\section{Analysis}

Stakeholders' responses were collected in paper format and a combined dataset from all 3 sites was created. Descriptive statistics were calculated using STATA, version 12 , and results were summarized in frequency tables and graphs. For nonparametric data comparisons, the MannWhitney U-test was used.

\section{Results}

\section{Participants}

In total, 58 stakeholders were identified and contacted in Cyprus, Greece and Israel, and 49 of them agreed to participate in the survey (84.5\% overall response rate). An overview and summary statistics of the participants across the 3 countries are provided in Table 1 (a detailed list of all participants is available on request). Of the 49 completed questionnaires, $14(28.6 \%)$ were obtained from regulatory authorities and 35 (71.4\%) from social stakeholders. A total of 13 (27\%) participants were health professionals (medical doctors, nursing personnel and public.

\section{Knowledge about DDS events and associated health effects}

All responders stated that they were familiar with the DDS phenomenon. The median perceived frequency of the DDS events was 6 episodes per year (range 1-24 episodes per year). Twenty-five (51\%) participants reported that DDS annual frequency is less than 10 episodes per year, while 14 participants (nearly 30\%) reported that it is 10 or more episodes per year. Similarly, among health professionals, only $38 \%$ reported an annual DDS frequency of $\geq 10$ episodes per year. In addition, it is noteworthy that one fifth of the responders did not know how often DDS events occur (Table 2). Spring (44\%) season was perceived as the season with the highest frequency of DDS events, followed by summer (31\%), fall (18\%) and winter $(8 \%)$.

\begin{tabular}{|c|c|c|c|}
\hline \multicolumn{4}{|c|}{$\begin{array}{l}\text { Table } 1 \text { Distribution of participants (regulatory authorities } \\
\text { and social stakeholders) and response rates according to } \\
\text { category/country, 2017-2018 }\end{array}$} \\
\hline \multirow[t]{2}{*}{ Type } & \multirow{2}{*}{$\begin{array}{l}\text { No. } \\
\text { participants } \\
\text { contacted }\end{array}$} & \multicolumn{2}{|c|}{ Responses } \\
\hline & & No. & $\%$ \\
\hline \multicolumn{4}{|l|}{ Category } \\
\hline Health & 5 & 5 & 100 \\
\hline Educational & 3 & 3 & 100 \\
\hline Environmental & 8 & 7 & 88 \\
\hline Patient/caregiver/teacher & 7 & 6 & 88 \\
\hline Medical & 8 & 6 & 75 \\
\hline Municipality & 11 & 7 & 64 \\
\hline Trade union & 3 & 3 & 100 \\
\hline Academic and research & 13 & 12 & 92 \\
\hline Total & 58 & 49 & 84 \\
\hline \multicolumn{4}{|l|}{ Country } \\
\hline Cyprus & 29 & 25 & 86 \\
\hline Crete (Greece) & 17 & 16 & 94 \\
\hline Israel & 12 & 8 & 67 \\
\hline Total & 58 & 49 & 84 \\
\hline
\end{tabular}

Almost all responders (87.9\%) were aware that DDS events may be associated with specific health effects. As their primary sources of information, they named scientific articles (32\%), the Internet (22\%) and coursework during academic studies (20\%). Less frequently reported sources of information were scientific conferences (11\%) and mass media (10\%). Most responders from regulatory authorities (71\%) instinctively acknowledged that elderly individuals and children are subpopulations susceptible to DDS; this was even higher among social stakeholders (74\% for the elderly and 77\% for children). Among health professionals the percentages were even higher with $85 \%$ suggesting vulnerability of the elderly and $92 \%$ of children. Figure 1, presents in detail, the distribution of responses on possible health effects associated to DDS events among regulatory authorities and social stakeholders. Respiratory conditions and allergies were the most frequently mentioned.

\section{Current practices in response to desert dust}

\begin{tabular}{lc}
\hline $\begin{array}{l}\text { Table } 2 \text { Perceived annual frequency (no. of episodes) of } \\
\text { desert dust storm (DDS) events from regulatory and social }\end{array}$ \\
\begin{tabular}{lc} 
respondents in Cyprus, Greece (Crete) and Israel, 2017-2018 \\
\hline $\begin{array}{l}\text { Perceived annual frequency of DDS } \\
\text { events }\end{array}$
\end{tabular} \\
$\begin{array}{c}\text { No. (\%) } \\
\text { responses }\end{array}$ \\
\hline 5 to $<10$ & $14(28.6)$ \\
10 to $<15$ & $11(22.4)$ \\
15 to $<20$ & $7(14.3)$ \\
$\geq 20$ & $3(6.1)$ \\
Don't know & $4(8.2)$ \\
\hline
\end{tabular}


Figure 1 Health effects of desert dust storm (DDS) events: distribution of unprompted responses on the knowledge of health effects associated with DDS events among regulatory authorities and social stakeholders in Cyprus, Greece (Crete) and Israel, 2017-2018

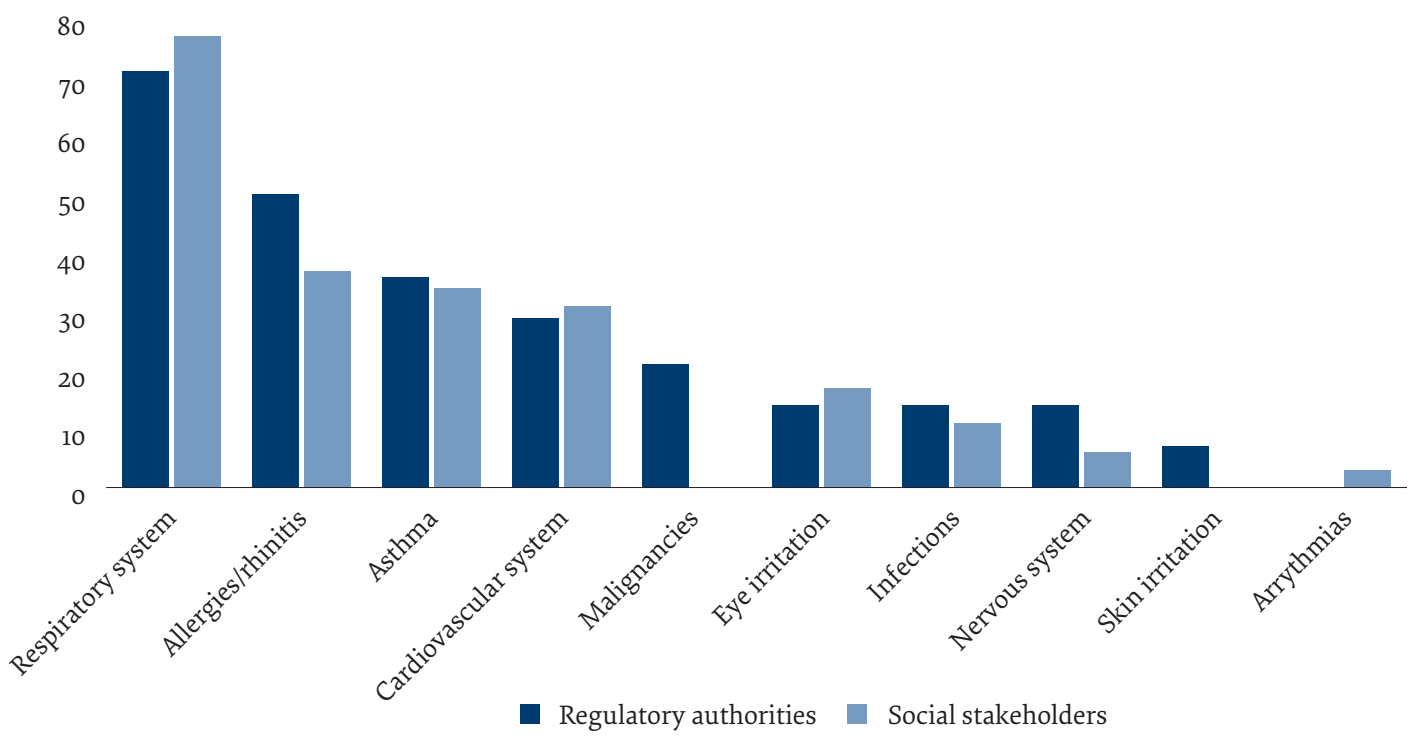

\section{storm events}

Approximately $42 \%$ of regulatory authorities and $22 \%$ of social stakeholders reported that they receive questions from the general public or vulnerable populations on the possible adverse health effects of DDS. However, $21 \%$ of regulatory authorities and $11 \%$ of social stakeholders did not know whether their organization receives questions from the public on this issue. Among the regulatory authorities that receive questions, $3(50 \%)$ provide standardized replies according to a pre-determined action plan. None of the social stakeholders that reported receiving questions from the public provides standardized replies.

Furthermore, of all the social stakeholders, only $29 \%$ believe that there is a national policy regarding DDS in their country. Another 34\% considered that a national policy regarding DDS events was lacking, while the remaining 37\% did not know whether a national policy exists or not. Even within the regulatory authorities' representatives, the proportion that considered that national legislation on DDS events is in place was still low, but relatively higher than among the social stakeholders (43\% versus 29\%). Four regulators (29\%) did not consider that a national policy exists while another 4 stakeholders $(29 \%)$ reported that they were unaware whether a national policy exists or not. Among health professionals, 54\% thought that a national policy exists, $31 \%$ that it does not exist and $15 \%$ were unaware whether a national policy exists or not. The majority $(69 \%)$ of the 35 social stakeholders participating in the study believe that vulnerable groups and decision-makers receive only partial information on the potential health impacts of DDS events. A small proportion (23\%) receive direct warnings on DDS events, usually only one day before the event. Nevertheless, only $9 \%$ actively disseminate information on DDS health effects to the public, specific vulnerable groups or their members.
Table 3 provides an overview of participants' responses when asked to assess the relevance of different public policy actions towards protecting vulnerable populations from DDS events. In general, regulatory authorities provided higher ratings to most of the suggested actions. The involvement of mass communications media and the implementation of information activities at the community level were given the highest rating by members of the regulatory authorities, while both groups assigned equal importance to the development of training materials for future professionals. Other findings included generally higher ratings for all proposed actions from health authorities compared with the ratings provided by educational and environmental authorities. Similarly, medical associations also tended to give higher ratings to the proposed actions compared with other social stakeholders.

\section{Desert dust storm events and indoor environment}

Both regulatory authorities and social stakeholders agree that DDS events result in increased concentration of air pollutants in indoor environments although there was some disagreement on the magnitude of this effect. More than half of the social stakeholders (51.4\%) consider that DDS events result in higher concentrations in indoor environments to some extent. Another significant fraction of social stakeholders reported that indoor concentrations are increased a lot (32.4\%), while a smaller proportion considered that the increase in indoor concentrations due to DDS events is small (13.5\%). Participants from regulatory authorities provided slightly more conservative estimates as $27.3 \%$ reported that indoor concentrations are increased only by a small amount, $45.6 \%$ to some extent and $27.3 \%$ a lot. Nevertheless, both groups agreed on the usefulness of air cleaning devices as a measure to mitigate the negative impacts of DDS events. 


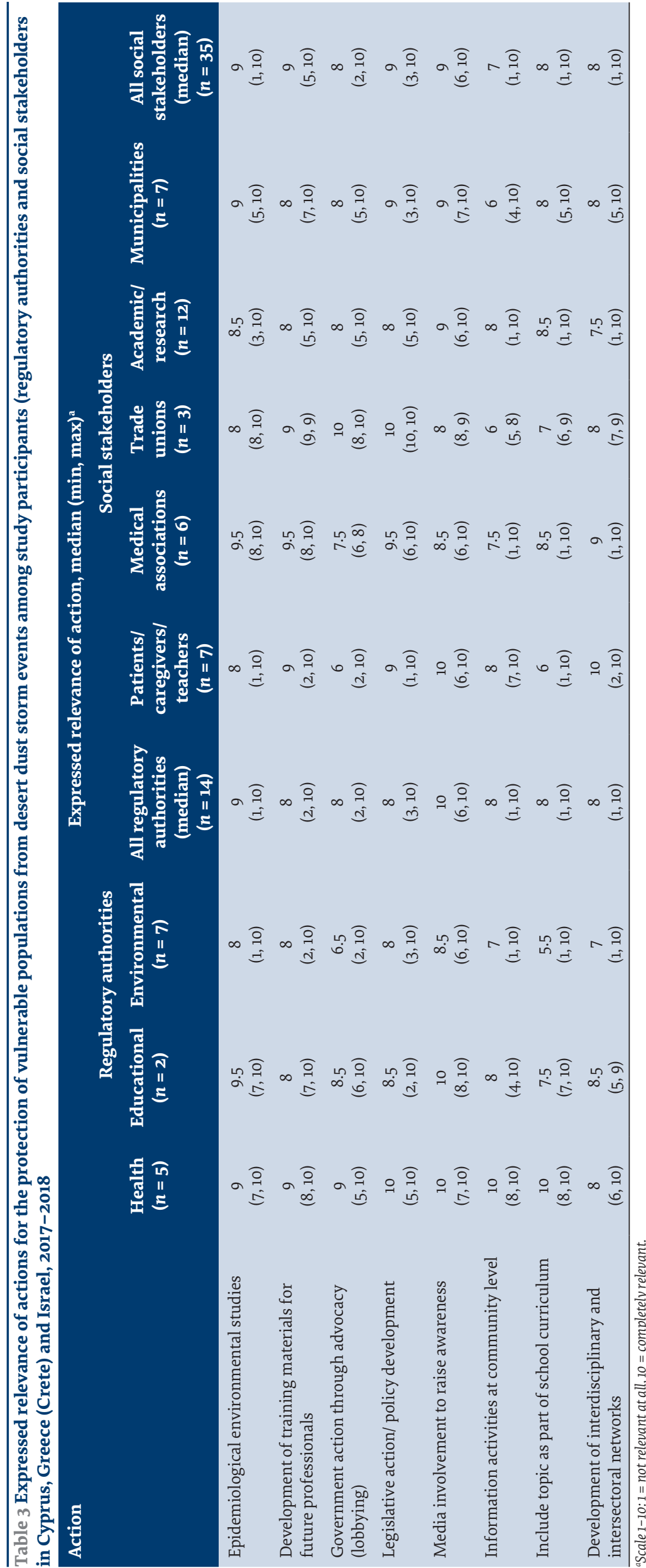

A positive response was provided by $72.7 \%$ of participants from regulatory authorities and $70.3 \%$ from the social stakeholders. Almost all of the remaining responders, replied that they were unaware of the usefulness of indoor air cleaners and only 3 social stakeholders $(8.1 \%)$ reported that they do not believe that air-cleaners would mitigate the negative impacts of DDS events. A positive opinion on the usefulness of air cleaners was also noted among health professionals $(70 \%)$.

In total, 29 out of 49 participants (59.2\%) provided responses on the annual cost of using such indoor air cleaners (8 responses from regulatory authorities and 21 from social stakeholders). There was a high level of agreement between the groups on the amount a household would be willing to spend for such a device per year. The median amount for regulatory authorities' representatives was 150 euros/year with an interquartile range (IQR) of 72.5-235, while the median amount for social stakeholders was 120 euros with an IQR of 100-300, $(P=0.767)$.

\section{Discussion}

The south-eastern Mediterranean is affected by DDS events in increasing frequency and intensity due to climate change (4). To our knowledge, this is the first study to explore the current knowledge, practices and perceptions of regulatory authorities and social stakeholders regarding the DDS phenomenon and associated health effects in the geographical region of the eastern Mediterranean. Despite the substantial level of concern for DDS in the 3 study areas, there is limited application of pre-determined action plans for these events. Furthermore, the majority of social stakeholders in the 3 areas believe that neither decision-makers nor the public are fully informed on the potential health impacts of DDS. Only a minority of them report receiving some form of early warnings for these events and even fewer disseminate this information to their members, vulnerable groups or the public.

Spring was identified as the season most frequently affected by DDS events, which is in agreement with findings of scientific observations (1), but most responders underestimated the overall frequency of the event. Previous studies have demonstrated that the region experiences approximately 15-30 events per year (32-34) or approximately 13-36 annual dust days $(1,35)$. In our study, only about $10 \%$ of the participants reported 
a similar or higher frequency. Almost all responders instinctively identified respiratory complications as the main health effect of DDS events, while other effects, particularly from the cardiovascular system, were greatly underestimated and were reported by fewer responders. In fact, numerous studies have already demonstrated a strong and consistent link between DDS events and cardiovascular mortality and morbidity both in Asia and Europe $(20,36,37)$. This discrepancy underlines the lack of knowledge of the wide body of evidence on the main health effects of DDS events (12) and poor dissemination of existing evidence to regional stakeholders.

Although both social stakeholders and regulatory authorities acknowledge that DDS may affect indoor air quality, their opinion on the magnitude of this effect was variable. Few studies have examined this aspect and shown that there is high infiltration of outdoor $\mathrm{PM}$ to the indoor environment during DDS events $(38,39)$. More specifically, in Israel the infiltration factor reached 0.82 for $\mathrm{PM}_{2.5}$ and 0.72 for $\mathrm{PM}_{10}$ during DDS events (39), while a study in Japan has shown that just leaving the window open for 10 minutes during a dust event resulted in a rapid increase in indoor particulate matter counts up to $70 \%$ of the outside particulate matter (38). However, it should be noted that infiltration factors also vary depending on the ventilation system, household floor level and presence of pets $(38-40)$, and fine particles are able to infiltrate more efficiently into the indoor environment compared with larger particles even when windows are closed (39). In this respect, the majority of the responders not surprisingly considered as beneficial the use of an indoor air cleaner as a measure to mitigate the negative impacts of DDS events. This view is in agreement with the findings of recent studies demonstrating the effectiveness of air cleaners to remove particulates from indoor air in households (41-43) and schools (44). Also of interest is that most of the responders were willing to spend 70 to 300 euros per year for such a device (including electricity consumption). This amount is realistic, taking into consideration that the retail cost of quality HEPA air cleaners ranges between US\$200 and US\$ 400 and electricity consumption of the most recent models is low (<120 Watts) (45).

The main strength of our study is that it captures for the first time the current perspectives and practices in regard to DDS events of regulatory authorities and a wide range of social stakeholders across 3 countries in the south-eastern Mediterranean. The only other study that focused on public health policy for DDS events was recently carried out in the Islamic Republic of Iran and focused on the preparedness challenges of the local health system in response to DDS. It demonstrated that senior policy-makers and executives were not fully familiar with DDS and the related health effects, the severity of the phenomenon, and the identification of high-risk areas. It also highlighted the lack of DDSspecific action plans and the need for integrated training programmes and increasing population awareness (46). Collectively these findings may assist the intercalation of scientists and stakeholders, which is an integral part of any participatory decision making process for the development of national and international policies (27). Failure to attend carefully to stakeholder interests, state of knowledge and perceptions in the past has been repeatedly shown to result in negative outcomes (47).
The findings of this study are expected to enhance cooperation among various actors and provide the foundation for stakeholders and regulatory authorities to define their responsibilities towards a range of intervention measures aiming to minimize DDS exposure and associated health problems. Furthermore, as DDS events constitute a common environmental health risk that is usually transboundary, originating from multiple dust sources and affecting multiple countries at once (4850), our study contributes towards the dissemination of knowledge and sharing of public health policies between the countries of the region. Although not all countries of the region experience the same intensity and frequency of DDS, international collaboration between regulatory authorities (meteorological forecasters, air pollution monitoring stations and health authorities) may facilitate the development of a regional, or even global, desert dust health warning system and transfer of best practices between countries, as suggested previously (51). In line with this approach, the ongoing European Union-funded InDust COST action aims to facilitate the development of an international network of scientists working on linking dust forecasting models and ground measurements with early warning systems (52).

It is suggested that DDS warnings be disseminated through multiple, pre-defined and well maintained notification channels and must be clear, consistent and accurate, targeting distinct audiences such as health care professionals, educators and outdoor workers as well as the general public (53). Warning messages should also be accompanied by specific evidence-based guidelines aimed at reducing the health impact of DDS, especially among vulnerable population groups. These guidelines can include behavioural adaptations to reduce exposure to $\mathrm{PM}_{10}$ by limiting time spend outdoors and reducing outdoor physical activities during DDS, while indoor concentrations of $\mathrm{PM}_{10}$ can be controlled using a HEPA air cleaner. The feasibility and effectiveness of these guidelines will be assessed in 2 large field studies focusing on children with asthma and elderly patients with atrial fibrillation as part of the demonstration project MEDEA (Mitigating the Health Effects of Desert Dust Storms Using Exposure-Reduction Approaches), which is funded by the European Union LIFE Programme (54).

Our study is also characterized by some limitations. We acknowledge that some of the organizations contacted, did not participate in the study and the possibility that our results may have been influenced by non-responder bias cannot be ruled out. Furthermore, the response rate was higher in Greece and Cyprus than in Israel, which may reflect cultural differences (mentality, unwillingness to share information), unfamiliarity with European collaborative projects as well as possible security concerns. Secondly, the participation in some categories, such as the medical and municipalities groups, was lower than in other categories. This could be largely attributed to their possible different attitudes toward DDS events (perceived less relevant to them) and their possible hesitation to share information due to lack of specific knowledge on the subject. Nevertheless, although the sample of surveyed participants was not homogeneous (particularly in terms of ethnicity and background), its diversity is representative of the study area and the researchers tried to saturate concepts by many well experienced participants. 


\section{Conclusion}

This study analysed the perceptions and practices of regulatory authorities and social stakeholders regarding DDS events in 3 countries in the south-eastern Mediterranean region. Our results demonstrate high awareness for this phenomenon and a good understanding of some of the related health effects among stakeholders in the 3 countries but also limited existence and hence application of pre-determined action plans for DDS events. Our findings are expected to inform and further support an ongoing public dialogue in the region for the development of intervention measures aimed at minimizing DDS exposure and associated health effects.

\section{Acknowledgement}

The authors would like to thank the representatives from the different stakeholders for their participation in the study.

Funding: This study was supported by the European Union LIFE project MEDEA (LIFE16 CCA/CY/oooo41).

Competing interests: None declared.

\section{Effets sanitaires des tempêtes de poussières désertiques dans le sud-est de la Méditerranée : perceptions et pratiques des parties prenantes locales \\ Résumé}

Contexte : Le sud-est de la Méditerranée subit fréquemment des tempêtes de poussières désertiques qui se sont révélées être associées à des effets néfastes sur la santé.

Objectifs : La présente étude a évalué les perceptions et les pratiques des autorités locales et des parties prenantes concernant les tempêtes de poussières, dans trois pays de la région : Chypre, la Grèce et Israël.

Méthodes : Entre octobre 2017 et avril 2018, nous avons demandé aux autorités de réglementation impliquées dans la protection du public contre les tempêtes de poussières ainsi qu'aux parties prenantes sociales des trois pays de remplir un questionnaire semi-structuré. Ce questionnaire portait sur leurs connaissances au sujet des tempêtes de poussières, leur perception de la relation entre ces dernières et les effets sur la santé et les mesures pertinentes adoptées pour protéger le public.

Résultats: Sur les 58 parties prenantes contactées, 49 ont participé à l'étude (taux de réponse de 84,5\%). Quatorze $(28,6 \%)$ étaient des autorités de réglementation et $35(71,4 \%)$ des parties prenantes sociales. Tous les répondants avaient des connaissances sur les tempêtes de poussières désertiques, mais plusieurs d'entre eux sousestimaient la fréquence des événements, tandis que la majorité $(73 \%)$ avait instinctivement indiqué que les personnes âgées, les enfants et les patients souffrant de troubles respiratoires étaient des sous-populations qui y sont sensibles. Néanmoins, $71 \%$ d'entre eux n'avaient pas connaissance de l'existence d'une politique nationale en matière de protection contre les tempêtes de poussières, ou considéraient qu'elle faisait défaut dans leur pays. Même si plusieurs parties prenantes ont indiqué avoir reçu des questions du grand public concernant les effets des tempêtes de poussières désertiques, seules quelques-unes y ont répondu selon un plan d'action prédéterminé.

Conclusions : À Chypre, en Grèce et en Israël, les autorités de réglementation et les parties prenantes sociales font preuve d'une bonne connaissance des tempêtes de poussières et de leurs effets sur la santé, bien que la mise en œuvre de plans d'action prédéterminés pour la protection du grand public soit limitée. À l'avenir, il sera nécessaire d'augmenter la sensibilisation à ce sujet parmi les parties prenantes et le grand public et d'élaborer des politiques nationales, notamment des mesures efficaces pour minimiser l'exposition aux tempêtes de poussières désertiques.

$$
\begin{aligned}
& \text { الآثار الصحية لأحداث العو اصف الترابية الصحر اوية في جنوب شرق البحر المتوسط: تصورات وممارسات الجهات } \\
& \text { صاحبة المصلحة المحلية }
\end{aligned}
$$

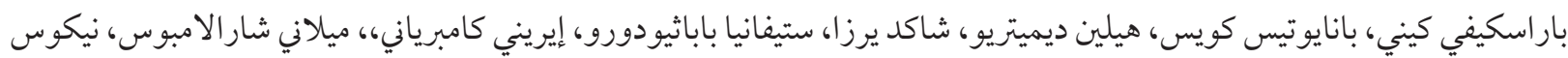

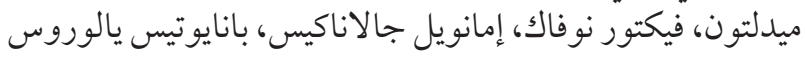

$$
\begin{aligned}
& \text { الخلاصة } \\
& \text { الخلفية: تشهد منطقة جنوب شرق المتوسط العديد من أحداث العواصف الترابية الصحر اوية التي ثبت ارتباطها بآثار صحية ضارة. }
\end{aligned}
$$

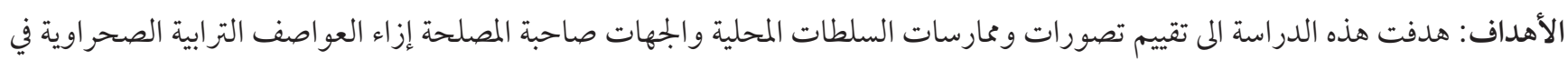

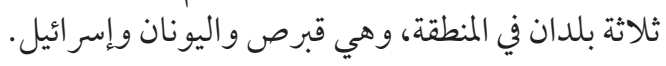




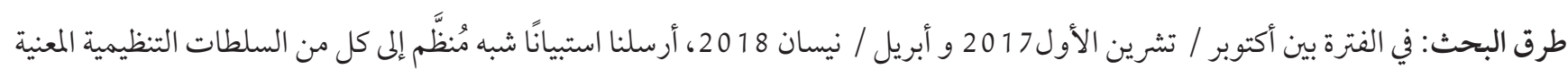

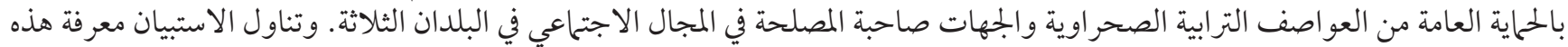

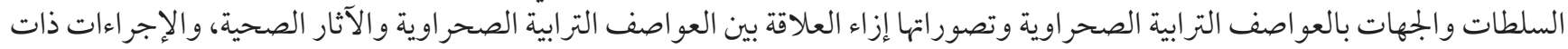
الصلة المتخذة من أجل حماية الجمهورو.

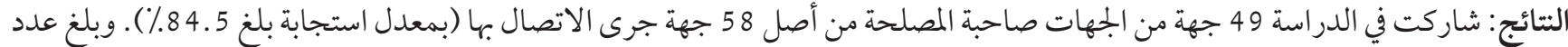

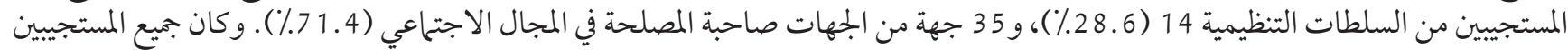

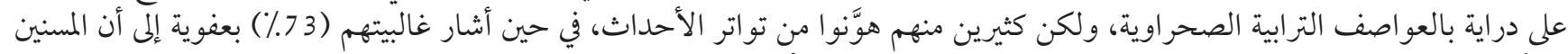

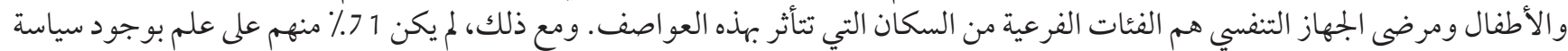

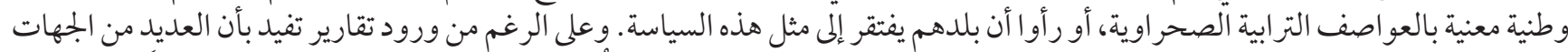

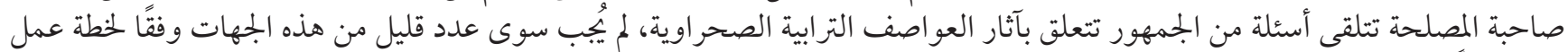
محددة سلفًا.

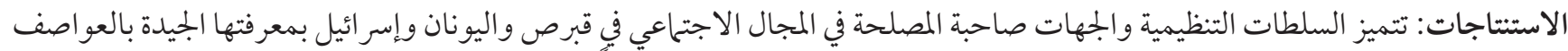

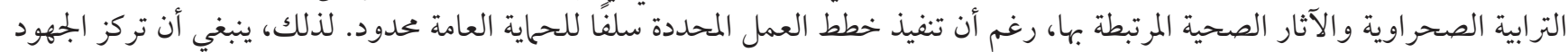

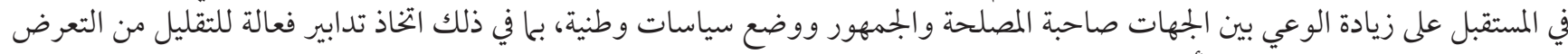

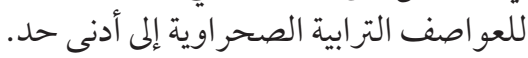

\section{References}

1. Achilleos S, Evans JS, Yiallouros PK, Kleanthous S, Schwartz J, Koutrakis P. PMio Concentration levels at an urban and background site in Cyprus: The impact of urban sources and dust storms. J Air Waste Manag Assoc. 2014;64(12):1352-60. doi:10.1080/1 0962247.2014 .923061

2. Querol X, Pey J, Pandolfi M, Alastuey A, Cusack M, Pérez N, et al. African dust contributions to mean ambient PM1o mass-levels across the Mediterranean Basin. Atmos Environ. 2009;43(28):4266-77. doi:10.1016/j.atmosenv.2009.06.013

3. Pey J, Querol X, Alastuey A, Forastiere F, Stafoggia M. African dust outbreaks over the Mediterranean Basin during 2001-2011: PMio concentrations, phenomenology and trends, and its relation with synoptic and mesoscale meteorology. Atmos Chem Phys. 2013;13(3):1395-410.

4. Ganor E, Osetinsky I, Stupp A, Alpert P. Increasing trend of African dust, over 49 years, in the eastern Mediterranean. J Geophys Res Atmos. 2010;115(7).

5. Goudie AS, Middleton NJ. The changing frequency of dust storms through time. Climatic Change. 1992;(20):197-225. doi:10.1007/ BFo0139839

6. Keil DE, Buck B, Goossens D, McLaurin B, Murphy L, Leetham-Spencer M, et al. Nevada desert dust with heavy metals suppresses IgM antibody production. Toxicol reports. 2018 Feb 9;5:258-69. doi:10.1016/j.toxrep.2018.01.006

7. Ghio AJ, Kummarapurugu ST, Tong H, Soukup JM, Dailey LA, Boykin E, et al. Biological effects of desert dust in respiratory epithelial cells and a murine model. Inhal Toxicol. 2014;26(5):299-309. doi:10.3109/08958378.2014.888109

8. He M, Ichinose T, Song Y, Yoshida Y, Bekki K, Arashidani K, et al. Desert dust induces TLR signaling to trigger Th2-dominant lung allergic inflammation via a MyD88-dependent signaling pathway. Toxicol Appl Pharmacol. 2016 Apr;296:61-72. doi:10.1016/j.taap.2016.02.011

9. Wang B, Li N, Deng F, Buglak N, Park G, Su S, et al. Human bronchial epithelial cell injuries induced by fine particulate matter from sandstorm and non-sandstorm periods: association with particle constituents. J Environ Sci (China). 2016;47:201-10. doi:10.1016/j.jes.2015.12.015

10. Münzel T, Gori T, Al-Kindi S, Deanfield J, Lelieveld J, Daiber A, et al. Effects of gaseous and solid constituents of air pollution on endothelial function. Eur Heart J. 2018 Oct 7;39(38):3543-50. doi:10.1093/eurheartj/ehy481

11. Chang C-C, Hwang J-S, Chan C-C, Wang P-Y, Cheng T-J. Effects of concentrated ambient particles on heart rate, blood pressure, and cardiac contractility in spontaneously hypertensive rats during a dust storm event. Inhal Toxicol. 2007 Jan 1;19(11):973-8. doi:10.1080/08958370701515399

12. Zhang X, Zhao L, Tong DQ, Wu G, Dan M, Teng B. A systematic review of global desert dust and associated human health effects. Atmosphere (Basel). 2016;7(12):158. https://doi.org/10.3390/atmos7120158

13. Moreira I, Linares C, Follos F, Sánchez-Martínez G, Vellón JM, Díaz J. Short-term effects of Saharan dust intrusions and biomass combustion on birth outcomes in Spain. Sci Total Environ. 2020;701:134755. doi:10.1016/j.scitotenv.2019.134755

14. Cox PA, Richer R, Metcalf JS, Banack SA, Codd GA, Bradley WG. Cyanobacteria and BMAA exposure from desert dust: a possible link to sporadic ALS among Gulf War veterans. Amyotroph Lateral Scler . 2009 Jan 1;10(Suppl. 2):109-17. doi:10.3109/17482960903286066 
15. Otani S, Onishi K, Mu H, Yokoyama Y, Hosoda T, Okamoto M, et al. The relationship between skin symptoms and allergic reactions to Asian dust. Int J Environ Res Public Health. 2012 Dec 10;9(12):4606-14. doi:10.3390/ijerph9124606

16. Tobías A, Caylà JA, Pey J, Alastuey A, Querol X. Are Saharan dust intrusions increasing the risk of meningococcal meningitis? Int J Infect Dis. 2011;15(7):e503. doi:10.1016/j.ijid.2011.03.008

17. Yang C-Y. Effects of Asian dust storm events on daily clinical visits for conjunctivitis in Taipei, Taiwan. J Toxicol Environ Health A. 2006 Oct 1;69(18):1673-80. doi:10.1080/15287390600630096

18. Mallone S, Stafoggia M, Faustini A, Paolo Gobbi G, Marconi A, Forastiere F. Saharan dust and associations between particulate matter and daily mortality in Rome, Italy. Environ Health Perspect. 2011;119(10):1409-14. https://doi.org/10.1289/ehp.1003026

19. Vodonos A, Friger M, Katra I, Avnon L, Krasnov H, Koutrakis P, et al. The impact of desert dust exposures on hospitalizations due to exacerbation of chronic obstructive pulmonary disease. Air Qual Atmos Heal. 2014;7:433-9. doi 10.1007/s11869-014-0253-Z

20. Middleton N, Yiallouros P, Kleanthous S, Kolokotroni O, Schwartz J, Dockery DW, et al. A 10-year time-series analysis of respiratory and cardiovascular morbidity in Nicosia, Cyprus: The effect of short-term changes in air pollution and dust storms. Environ Health. 2008;7:1-16. doi:10.1186/1476-069X-7-39

21. Neophytou AM, Yiallouros P, Coull BA, Kleanthous S, Pavlou P, Pashiardis S, et al. Particulate matter concentrations during desert dust outbreaks and daily mortality in Nicosia, Cyprus. J Expo Sci Environ Epidemiol. 2013;23(3):275-80. doi:10.1038/ jes.2013.10

22. Im H-J, Kwon H-J, Ha M, Lee SG, Hwang S-S, Ha EH, et al. [Public perceptions of the risk of Asian dust storms in Seoul and its metropolitan area.] J Prev Med Public Health]. 2006 May;39(3):205-12 (in Korean). PMID:16764494

23. Crosby BC, Bryson JM. Leadership for the common good: tackling public problems in a shared-power world, 2nd ed. San Francisco: John Wiley \& Sons; 2005.

24. Welp M, de la Vega-Leinert A, Stoll-Kleemann S, Jaeger CC. Science-based stakeholder dialogues: theories and tools. Glob Environ Chang. 2006;16(2):170-81. doi:10.1016/j.gloenvcha.2005.12.002

25. Bryson JM. What to do when stakeholders matter: Stakeholder identification and analysis techniques. Public Manag Rev. 2004;6(1):21-53. doi:10.1080/14719030410001675722

26. Brugha R, Varvasovszky Z. Stakeholder analysis: a review. Health Policy Plan. 2000;15(3):239-46. doi:10.1093/heapol/15.3.239

27. Reed MS. Stakeholder participation for environmental management: a literature review. Biol Conserv. 2008;141(10):2417-31. https://doi.org/10.1016/j.biocon.2008.07.014

28. Renn O. White paper on risk governance: toward an integrative framework. In: Renn O, Walker KD, eds. Global risk governance. International Risk Governance Council Bookseries, vol 1. Dordrecht: Springer; 2005. doi:10.1007/978-1-4020-6799-0_1

29. Gill P, Stewart K, Treasure E, Chadwick B. Methods of data collection in qualitative research: interviews and focus groups. Bdj. 2008 Mar 22;204:291.

30. Callaghan S, Corra L, Hanvey L, Leoni M, Monti V. Profile of children's environmental health in Argentina. Buenos Aires: Ministerio de Salud de la Argentina, la Sociedad Argentina de Pediatría, la Asociación Argentina de Médicos por el Medio Ambient, Canadian Institute of Child Health; 2007.

31. Golnaraghi M. Global assessment report on disaster reduction: thematic progress review sub-component on early warning systems. Geneva: World Meteorological Organization; 2009:1-32.

32. Kopanakis I, Mammi-Galani $\square$, Pentari D, Glytsos T, Lazaridi M. Ambient particulate matter concentration levels and their origin during dust event episodes in the Eastern Mediterranean. Aerosol Sci Engineer 2. 2018:61-73. doi:10.1007/s41810-018-0023-7

33. Ganor E. The frequency of Saharan dust episodes over Tel Aviv, Israel. Atmos Environ. 1994;28(17):2867-71. doi:10.1016/13522310(94)90087-6

34. Kaskaoutis DG, Kosmopoulos PG, Nastos PT, Kambezidis DH, Sharma M, Mehdi W. Transport pathways of Sahara dust over Athens, Greece as detected by MODIS and TOMS. Geomatics, Nat Hazards Risk. 2012 Feb 1;3(1):35-54.

35. Trianti SM, Samoli E, Rodopoulou S, Katsouyanni K, Papiris SA, Karakatsani A. Desert dust outbreaks and respiratory morbidity in Athens, Greece. Environ Heal A Glob Access Sci Source. 2017;16(1):1-9. doi:10.1186/s12940-017-0281-X

36. Renzi M, Forastiere F, Calzolari R, Cernigliaro A, Madonia G, Michelozzi P, et al. Short-term effects of desert and non-desert PMioon mortality in Sicily, Italy. Environ Int. 2018;120(April):472-9. doi:10.1016/j.envint.2018.08.016

37. Alessandrini ER, Stafoggia M, Faustini A, Gobbi GP, Forastiere F. Saharan dust and the association between particulate matter and daily hospitalisations in Rome, Italy. Occup Environ Med. 2013;70(6):432-4. doi:10.1136/oemed-2012-101182

38. Kanatani KT, Okumura M, Tohno S, Adachi Y, Sato K, Nakayama T. Indoor particle counts during Asian dust events under everyday conditions at an apartment in Japan. Environ Health Prev Med. 2014;19(1):81-8. doi:10.1007/s12199-013-0356-4

39. Krasnov H, Katra I, Novack V, Vodonos A, Friger MD. Increased indoor PM concentrations controlled by atmospheric dust events and urban factors. Build Environ. 2015;87:169-76. doi:10.1016/j.buildenv.2015.01.035

40. Kuo HW, Shen HY. Indoor and outdoor PM2.5 and PM1o concentrations in the air during a dust storm. Build Environ. 2010;45(3):610-4. doi:10.1016/j.buildenv.2009.07.017

41. Ciuzas D, Prasauskas T, Krugly E, Jurelionis A, Seduikyte L, Martuzevicius D. Indoor air quality management by combined ventilation and air cleaning: an experimental study. Aerosol Air Qual Res. 2016;16(10):2550-9. doi:10.4209/aaqr.2015.10.0577 
42. Lanphear BP, Hornung RW, Khoury J, Yolton K, Lierl M, Kalkbrenner A. Effects of HEPA air cleaners on unscheduled asthma visits and asthma symptoms for children exposed to secondhand tobacco smoke. Pediatrics. 2011;127(1):93-101. doi:10.1542/ peds.2009-2312

43. Butz AM, Matsui EC, Breysse P, Curtin-Brosnan J, Eggleston P, Diette G, et al. A randomized trial of air cleaners and a health coach to improve indoor air quality for inner-city children with asthma and secondhand smoke exposure. Arch Pediatr Adolesc Med. 2011;165(8):741-8. doi:10.1001/archpediatrics.2011.111

44. Jhun I, Gaffin JM, Coull BA, Huffaker MF, Petty CR, Sheehan WJ, et al. School environmental intervention to reduce particulate pollutant exposures for children with asthma. J Allergy Clin Immunol Pr. 2017;5(1):154-9. doi:10.1016/j.jaip.2016.07.018

45. Liu G, Xiao M, Zhang X, Gal C, Chen X, Liu L, et al. A review of air filtration technologies for sustainable and healthy building ventilation. Sustain Cities Soc. 2017;32(April):375-96.

46. Allahbakhshi K, Ghomian Z, Jazani RK, Khorasani-Zavareh D. Preparedness challenges of the Iranian health system for dust and sand storms: a qualitative study. J Educ Health Promot. 2019 Jun 27;8:114. doi:10.4103/jehp.jehp_470_18

47. Nutt PC. Why decisions fail: avoiding the blunders and traps that lead to debacles. San Francisco: Berrett-Koehler Publishers; 2002.

48. Achilleos S, Mouzourides P, Kalivitis N, Katra I, Kloog I, Kouis P, et al. Spatio-temporal variability of desert dust storms in Eastern Mediterranean (Crete, Cyprus, Israel) between 2006 and 2017 using a uniform methodology. Sci Total Environ. 2020 Apr;714:136693. doi:10.1016/j.scitotenv.2020.136693

49. Soleimani Z, Teymouri P, Darvishi Boloorani A, Mesdaghinia A, Middleton N, Griffin DW. An overview of bioaerosol load and health impacts associated with dust storms: A focus on the Middle East. Atmos Environ. 2020;223:117187.

50. Gherboudj I, Naseema Beegum S, Ghedira H. Identifying natural dust source regions over the Middle-East and North-Africa: estimation of dust emission potential. Earth-Science Rev. 2017;165:342-55.

51. Sprigg WA. Dust storms, human health and a global early warning system. In: Steinberg SL, Sprigg WA, eds. Extreme weather, health, and communities: interdisciplinary engagement strategies. Cham: Springer International Publishing; 2016:59-87.

52. Nemuc A, Mona L, Waldhauserova P, Tobias A, Monteiro A, Kazadzis S, et al. COST Lecture 2019 AE GM Barcelona: International Network to Encourage the Use of Monitoring and Forecasting Dust Products (InDust) How does Cambridge Core Share work? European Review: 2020;1-15

53. Kuligowski E, Dootson P. Emergency notification: warnings and alerts. Encyclopedia of wildfires and wildland-urban interface (WUI) fires. Cham: Springer International Publishing; 2018:1-9. https://doi.org/10.1007/978-3-319-51727-8_48-1

54. Mitigating the health effects of desert dust storms using exposure-reduction approaches (MEDEA). ClinicalTrials.gov identifier: NCT03503812. Bethesda, Maryland: US National Library of Medicine; 2018 (https://clinicaltrials.gov/ct2/show/NCT03503812, accessed 25 April 2021). 